\title{
Avaliação da vacinação anti-rábica e da suplementação com probiótico na resposta imune humoral em bovinos
}

\section{Evaluation of anti-rabies vaccination and supplementation with probiotic in the humoral immune response in cattle}

\author{
Luciene Aparecida Ferreira ${ }^{1}$; Paulo Eduardo Pardo²; Neuza Maria Frazatti-Gallina ${ }^{3}$; \\ Regina Maria Mourão-Fuches ${ }^{3}$; Daniella Cristina Ventini³; Sérgio do Nascimento \\ $\mathrm{Kronka}^{2}$; Sandro Eduardo Arenas ${ }^{2}$; Luis Souza Lima de Souza Reis ${ }^{4 *}$
}

\section{Resumo}

Objetivou-se avaliar a resposta imune humoral a uma nova vacina anti-rábica, desenvolvida no Instituto Butantan em bovinos primovacinados e o efeito do probiótico nesta resposta. Trinta e quatro bovinos da raça Nelore com idade de 15 meses foram divididos aleatoriamente em 2 grupos (17 bovinos/grupo): os animais foram vacinados no dia zero e um dos grupos recebeu uma mistura mineral com probiótico (GP), enquanto o outro apenas a mistura (GC). Colheu-se sangue dos animais nos dias 0,75 e 150 após a vacinação para determinação dos títulos de anticorpos anti-rábicos neutralizantes pela técnica de soroneutralização em células $\mathrm{BHK}_{21}$ (RFFIT). Foram encontrados títulos de anticorpos protetores $(\geq 0,5$ $\mathrm{UI} / \mathrm{mL}$ ) em $82,4 \%$ dos animais do grupo GP e $76,5 \%$ do grupo GC. Não houve diferença significativa $(\mathrm{p}>0,05)$ nos títulos de anticorpos entre os soros coletados dos dois grupos de animais nos dias 75 e 150 . Verificou-se também que para ambos os grupos no dia 150 houve uma redução significativa $(\mathrm{p}<0,01)$ nos títulos de anticorpos. Conclui-se que a vacina anti-rábica é eficiente em produzir soroconversão e em manter os títulos de anticorpos em bovinos primovacinados. A ingestão do probiótico não interferiu na resposta imune humoral anti-rábica.

Palavras-chave: Probiótico, resposta imune humoral, vacina anti-rábica, anticorpos, bovino

\begin{abstract}
This study evaluated the humoral immune response of a new rabies vaccine developed by the Instituto Butantan (potency of $3.27 \mathrm{UI} / \mathrm{ml}$ ) in primovaccinated cattle and the effect of probiotic on this response. Thirty-four 15-month old Nelore cattle were randomly divided into 2 groups (17 animals/group). All the animals were vaccinated on day 0 (zero) and then animals in one group received probiotic added to a mineral mixture (GP) while the others were given only the mineral mixture (GC). Blood samples were collected on days 0,75 and 150 for rabies neutralizing antibodies titers by seroneutralization assay on BHK $_{21}$ cells (RFFIT). Protective antibody titers $(\geq 0.5 \mathrm{UI} / \mathrm{mL})$ were found in $82.4 \%$ of the animals from GP and in $76.5 \%$ of the animals from GC and no statistical difference ( $\mathrm{p}>0.05)$ between antibody titers in GP and GC was detected on days 75 and 150. It was also observed that in both groups antibody titers was decreased on day $150(\mathrm{p}<0.01)$. In conclusion, the tested rabies vaccine promotes efficient soroconversion and keeps antibody levels in primovaccinated cattle, but probiotic does not affect the humoral anti-rabies immune response.
\end{abstract}

Key words: Probiotic, humoral immune response, rabies vaccination, antibodies, cattle

\footnotetext{
1 Mestranda em Ciência Animal, Universidade do Oeste Paulista - UNOESTE, Presidente Prudente, SP. E-mail: centraldepesquisaepublicacoes@yahoo.com.br.

2 Docente do Departamento de Clínica Médica - Universidade do Oeste Paulista - UNOESTE, Presidente Prudente, SP.

3 Laboratório de Raiva, Instituto Butantan, São Paulo, SP.

4 Doutorando em Medicina Veterinária, Universidade Estadual Paulista - FMVZ/UNESP

* Autor para correspondência
} 


\section{Introdução}

A raiva é uma enfermidade infecciosa viral causada pelo vírus da família Rhabdoviridae, gênero Lyssavirus (GOMES et al., 2007; LIMA et al., 2005; SCHEFFER et al., 2007). Esta enfermidade é uma das principais zoonoses mundiais, que causa encefalite fatal, acomete todos os mamíferos, tem ampla distribuição geográfica (ALBAS et al., 2006; FRANKA et al., 2004; LIMA et al., 2005) e é transmitida para os bovinos, principalmente pelo morcego hematófago Desmodus rotundus (GOMES; UIEDA; LATORRE, 2006; LIMA et al., 2005; SCHEFFER et al., 2007). Esta doença causa a morte de cerca de 100 a 500 mil bovinos por ano na América Latina causando prejuízo de aproximadamente 50 milhões de dólares (LIMA et al., 2005) e somente no Brasil na ordem de 30 a 40 mil bovinos/ano segundo o Ministério da Agricultura. Isso representa prejuízos diretos de 15 milhões de dólares e indiretos de 22,5 milhões de dólares. Para fazer o controle desta enfermidade, a vacinação contínua dos bovinos é o método mais efetivo, de menor custo e reduz as perdas econômicas (ALBAS et al., 2006; LIMA et al., 2005; PIZA et al., 2002).

Os probióticos são benéficos para a saúde dos animais e seres humanos. Dentre os efeitos benéficos dos probióticos, estão: são utilizados como promotores de crescimento aumentando o ganho de peso (ARENAS et al., 2007), impedem a colonização da mucosa intestinal por bactérias patogênicas e aumentam a resposta imune humoral (ARENAS et al., 2005).

Objetivou-se avaliar a resposta imune humoral de bovinos primovacinados a uma nova vacina antirábica de uso veterinário e o efeito da suplementação com probiótico nessa resposta.

\section{Material e métodos}

O experimento foi desenvolvido nos meses de maio a outubro de 2006 com o período experimental de 150 dias, no município de Presidente Prudente, extremo oeste do estado de São Paulo, Brasil (latitude $22^{\circ} 07^{\prime}$ 04" e longitude $51^{\circ} 22^{\prime}$ 57') com precipitação anual de média de $1.244 \mathrm{~mm}$, umidade relativa do ar de aproximadamente $65,5 \%$, temperatura média anual de aproximadamente de $28{ }^{\circ} \mathrm{C}$ e altitude de 475 metros. Utilizaram-se 34 bovinos, machos inteiros da raça Nelore (Bos taurus indicus) com idade de, aproximadamente, 15 meses e divididos aleatoriamente em 2 grupos (17 bovinos/ grupo): o grupo controle (GC) recebeu mistura mineral sem probiótico e no grupo probiótico (GP) os animais foram suplementados com mistura mineral adicionada de probótico. Os animais do GP consumiram 4 gramas de probiótico/animal/dia durante o período experimental.

Após 30 dias de ajuste ao novo suplemento mineral, ao probiótico e às condições de manutenção, iniciou-se o período de observação experimental, que durou 150 dias.

Os piquetes utilizados por ambos os grupos de bovinos eram semelhantes na topografia e composição botânica, sendo formados por Brachiaria brizantha. O sistema de pastejo adotado foi o extensivo.

As amostras de sangue dos bovinos foram colhidas nos dias 0,75 e 150. Para isso, os bovinos foram levados no período da manhã para o curral, contidos em tronco de contenção e $10 \mathrm{~mL}$ de sangue de cada animal foi colhido por meio da punção da veia jugular em tubos à vácuo sem anticoagulante e centrifugados a $2.500 \mathrm{rpm}$ por 10 minutos. Então as amostras de soro foram acondicionadas em tubos de plásticos $1,5 \mathrm{~mL}$ e armazenadas por congelação a $-20^{\circ} \mathrm{C}$ para posterior determinação do título de anticorpos neutralizantes anti-rábicos.

Os títulos de anticorpos neutralizantes antirábicos foram determinados por meio da técnica de soroneutralização em células $\mathrm{BHK}_{21}$, teste esse baseado no Rapid Fluorescent Focus Inhibition Test - RFFIT (SMITH; YAGER; BAER, 1996) e no Fluorescent Inhibition Microtest - FIMT (ZALAN; WILSON; PUKITIS, 1979). 
Foiutilizadaumanovavacinaanti-rábicainativada, liofilizada e de uso veterinário, desenvolvida no Instituto Butantan (IB), já previamente testada em camundongos, cães e gatos. Esta vacina foi produzida a partir de suspensões virais obtidas de culturas de células $\mathrm{BHK}_{21}$ infectadas com o vírus rábico PV (Pasteur Virus), concentrada por filtração tangencial, purificada por cromatografia, inativada pela $\beta$-propiolactona e liofilizada. Na liofilização foi utilizada como estabilizador a albumina eqüina. O lote de vacina utilizado (IB-VR/BHK21-01/03) apresentou a potência de 3,17 UI/mL, determinada pelo teste NIH (WILBUR; AUBERT, 1996).

No dia zero do experimento, foi aplicada em todos os bovinos uma dose de $2 \mathrm{~mL}$ de vacina por via subcutânea.

Utilizou-se um probiótico comercial devidamente registrado e aprovado pelo Ministério da Agricultura, Pecuária e Abastecimento (MAPA), composto por: Lactobacilus acidophilus, Estreptococus faecium, Bifedobacterium thermoplhilum, Bifedobacterium longum, amilase, celulase, protease, lipase, pectinase, e zinco.

A mistura mineral utilizada foi a Matsuda Fós ${ }^{\circledR}$, produzida por Matsuda Sementes e Nutrição Animal, Álvares Machado, SP, Brasil, contendo para cada Kg de mistura: cálcio $140 \mathrm{~g}$, fósforo $65 \mathrm{~g}$, cobalto 107 $\mathrm{g}$, iodo $5 \mathrm{~g}$, magnésio $5 \mathrm{~g}$, cobre $1.550 \mathrm{mg}$, enxofre $9 \mathrm{~g}$, sódio $148 \mathrm{~g}$, ferro $1.120 \mathrm{mg}$, manganês 1.100 $\mathrm{mg}$, níquel $30 \mathrm{mg}$, selênio $14 \mathrm{mg}$, zinco $4.000 \mathrm{mg}$, Flúor (máx.) $650 \mathrm{mg}$, sol. do $\mathrm{P}$ em ac. cítrico 2\% (min.) 95\%. Neste suplemento mineral adicionou-se 0 e $66,7 \mathrm{~g}$ de probiótico/Kg de suplemento.

O consumo diário médio/animal de ambos os suplementos minerais foram de $60 \mathrm{~g}$ durante o período experimental, onde se determinou que nesse período os animais do grupo GP consumiram $4 \mathrm{~g}$ de probiótico/dia.

Os dados foram submetidos à análise de variância bifatorial (teste F) e as médias comparadas pelo teste de Tukey. Em todas as análises considerouse o nível de 5\% de probabilidade (BANZATTO; KRONKA, 2006).

\section{Resultados e discussão}

No dia zero os soros dos animais não apresentaram anticorpos neutralizantes para a raiva, mostrando que os bovinos não haviam tido contato com o vírus rábico selvagem ou vacinal e os animais do grupo GP já estavam consumindo o probiótico por 30 dias antes da vacinação. Assim, as variações encontradas nos títulos de anticorpos anti-rábicos nos soros desses animais durante o experimento foram induzidas pela vacinação anti-rábica realizada no dia zero e pela administração ou não do probiótico.

A Organização Mundial de Saúde (OMS) preconiza que é necessário o título de anticorpos neutralizantes anti-rábico igual ou superior a $0,5 \mathrm{UI} /$ $\mathrm{mL}$ (Unidade Internacional UI/mL) para proteger os seres humanos dos riscos da infecção com o vírus rábico. Mas Sihvonen, Kulonen e Neuvonen (1994), Albas et al. (1998), Benišek et al. (2000), Rodrigues da Silva et al. (2000) e Albas et al. (2005) defendem a teoria de que este título de anticorpos neutralizantes anti-rábico também é o mínimo protetor para os bovinos.

Primeiramente notou-se que a resposta imune humoral anti-rábica nos bovinos dos grupos GC e GP foi heterogênea, ficando confirmada pelo elevado coeficiente de variação (C.V.) dos títulos de anticorpos, para grupos (C.V.=137,19\%) e dias de observação (C.V.= 57,48\%), apresentando animais que não responderam à vacinação (títulos de anticorpos $<0,50 \mathrm{UI} / \mathrm{mL}$ ) intercalados com outros que apresentaram títulos de anticorpos protetores mínimos $(\geq 0,50 \mathrm{UI} / \mathrm{mL})$ a elevados. Este fato também foi observado por Ciuchini et al. (1981), Albas et al. (1998, 2005), Giometti et al. (2006) e Maria et al. (2007) avaliando a resposta imune humoral a outras vacinas anti-rábicas. Portanto, esta variação nos títulos de anticorpos nos bezerros pode ser uma característica fisiológica da resposta imune humoral anti-rábica em bovinos primovacinados.

Os resultados obtidos mostraram que não houve efeito da interação entre grupos experimentais e dias de observação. A Figura 1 mostra que no 
grupo tratado com probiótico (GP) os títulos de anticorpos anti-rábicos são 94\% e 54\% maiores do que os do grupo controle nos dias 75 e 150 após a vacinação, respectivamente. Mesmo assim, não houve diferença significativa ( $p>0,05)$ nos títulos de anticorpos entre os tratamentos em ambos os dias após a vacinação. Portanto neste experimento, não foi observada a ação imunomoduladora específica do probiótico. Entretanto, Arenas et al. (2005), estudando o efeito da administração do probiótico Proenzime ${ }^{\circledR}$ para bovinos primovacinados contra a raiva relataram aumento significativo nos títulos de anticorpos anti-rábicos nos bovinos, 30 e 60 dias após a vacinação. Comparando-se esses dados com outros em que se usou o probiótico para aumentar a resposta imune na vacinação anti-rábica, podemos sugerir que quando se usa uma vacina com maior potência e liofilizada o uso desse imunomodulador não tem nenhuma relevância.

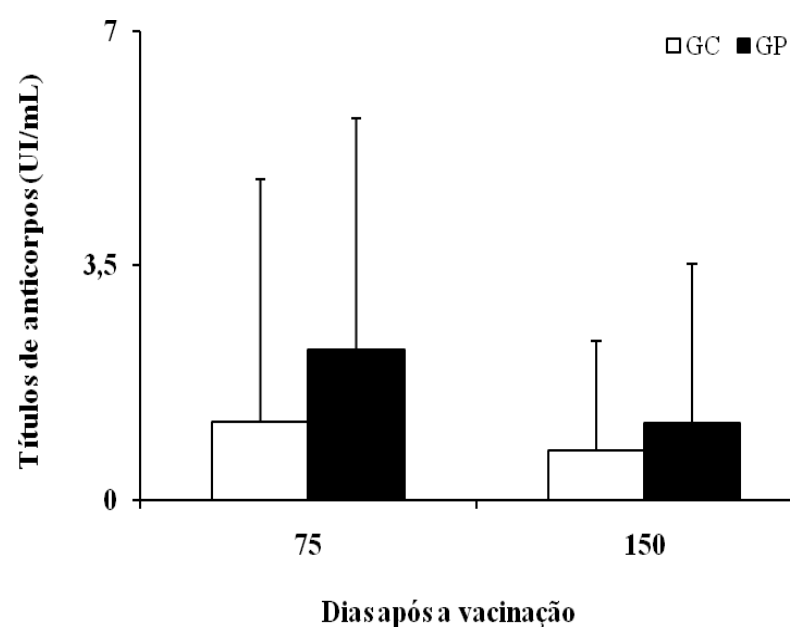

Figura 1. Títulos médios ( + desvio padrão) de anticorpos anti-rábicos de bovinos Nelore primovacinados e suplementados (Gc) ou não (GP) com $4 \mathrm{~g}$ de probiótico/ animal/dia adicionados na mistura mineral.
Os resultados apresentados na Figura 1 mostram que independentemente do uso ou não do probiótico os bovinos primovacinados contra a raiva apresentaram títulos de anticorpos antirábicos elevados em até 150 dias após a vacinação. Além disso, com apenas uma dose da vacina do IB observou-se uma elevada porcentagem de bovinos que apresentaram títulos de anticorpos considerados protetores nos dias 75 (76,5\% e 82,4\% de animais nos grupos GC e GP, respectivamente) e 150 (76,5\% dos animais de ambos os grupos experimentais). Estes resultados comprovam que a vacina antirábica utilizada neste experimento tem elevada eficiência em produzir e manter a soroconvesão nos bovinos primovacinados contra a raiva por longo período de tempo.

$\mathrm{Na}$ Figura 2 observa-se que apesar de haver uma redução significativa $(\mathrm{p}<0,01)$ nos títulos de anticorpos dos bovinos nos dois grupos (GC e GP) 150 dias após a vacinação, esses permaneceram elevados quando se leva em consideração o título necessário para proteger o animal $(\geq 0,50 \mathrm{UI} / \mathrm{mL})$. Os valores encontrados foram 1,5 e 2,3 vezes maiores do que o considerado protetor nos grupos GC e GP, respectivamente. Além disso, foi observada uma elevada porcentagem de bovinos $(75,6 \%)$ protegidos. Esta redução nos títulos de anticorpos anti-rábicos é um efeito fisiológico da resposta imune humoral em bovinos primovacinados contra a raiva, pois este fato também foi observado por Albas et al. (1998, 2005), Giometti et al. (2006) e Maria et al. (2007) avaliando a resposta imune humoral a outras vacinas anti-rábicas para bovinos devidamente liberadas, registradas e aprovadas pelo Ministério da Agricultura, Pecuária e Abastecimento. 


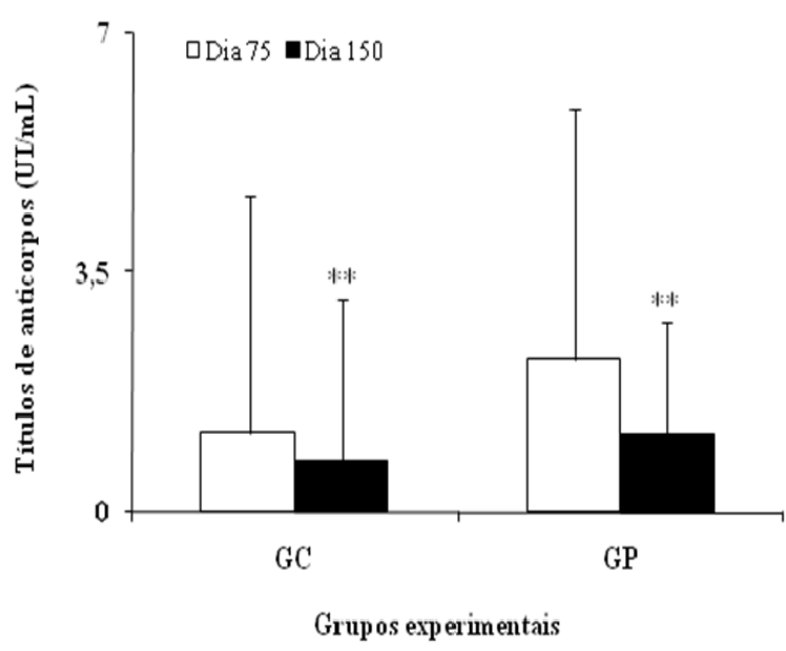

Figura 2. Títulos médios (+ desvio padrão) de anticorpos anti-rábicos de bovinos Nelore primovacinados e suplementados (Gc) ou não (GP) com $4 \mathrm{~g}$ de probiótico/ animal/dia adicionados na mistura mineral. ** indicam diferença significativa entre os dias de observação $(\mathrm{p}<0,01)$.

Apesar da vacina avaliada neste experimento ter excelente capacidade de induzir a soroconversão e de manter os títulos de anticorpos anti-rábicos considerados protetores nos bovinos primovacinados contra a raiva por longos períodos, estes resultados não dispensam a necessidade da aplicação da dose de reforço em bovinos primovacinados conforme preconizado pelo Programa de Controle da Raiva em Herbívoros do Instituto Pasteur.

\section{Conclusões}

Os resultados obtidos permitiram concluir que a vacina anti-rábica desenvolvida no Instituto Butantan teve elevada eficiência em induzir a soroconversão e em manter os títulos de anticorpos anti-rábicos em bovinos primovacinados por até 150 dias após a vacinação e que a suplementação da mistura mineral com probiótico não interferiu na resposta imune humoral anti-rábica.

\section{Agradecimentos}

À Matsuda Sementes e Nutrição Animal e também ao Instituto Butantam pelo incentivo, apoio e patrocínio deste experimento.

\section{Referências}

ALBAS, A.; FONTOLAN, O. L.; PARDO, P. E.; BREMER NETO, H.; SARTORI, A. Interval between first dose and booster affected antibody production in cattle vaccinated against rabies. Journal of Venomous Animals and Toxins including Tropical Diseases, Botucatu, v. 12, n. 3, p. 476-486, 2006.

ALBAS, A.; PARDO, P. E.; BREMER-NETO, H.; GALLINA, N. M. F.; MOURÃO FUCHES, R. M.; SARTORI, A. Vacinação anti-rábica em bovinos: comparação de cinco esquemas vacinais. Arquivos do Instituto Biológico, São Paulo, v. 72, n. 2, p. 153-159, 2005.

ALBAS, A.; PARDO, P. E.; GOMES, A. A. B.; BERNARDI, F.; ITO, F. H. Effect of a booster-dose of rabies vaccine on the duration of virus neutralizing antibody titers in bovine. Revista da Sociedade Brasileira de Medicina Tropical, Uberaba, v. 31, n. 4, p. 367-371, 1998.

ARENAS, S. E.; REIS, L. S. L. S.; FRAZATTIGALLINA, N. M.; FUJIMURA, S. H.; BREMER NETO, H.; MESSAS, A. C.; PARDO, P. E. Proenzime ${ }^{\circledR}$ probiotic increases the humoral immune response in bovines immunized with the rabies vaccine. In: INTERNATIONAL CONFERENCE RABIES ON RABIES IN THE AMERICAS, 16., 2005, Ottawa. Anais... Ottawa: Canadian Food Inspection Agency, 2005. p. 99.

ARENAS, S. E.; REIS, L. S. L. S.; FRAZATTIGALLINA, N. M.; GIUFFRIDA, R.; PARDO, P. E. Efeito do probiótico proenzime ${ }^{\circledR}$ no ganho de peso em bovinos. Archivos de Zootecnia, Córdoba, v. 56, n. 213, p. $75-78,2007$

BANZATTO, D. A.; KRONKA, S. N. Experimentação agrícola. 4. ed. Jaboticabal: FUNEP, 2006.

BENIŠEK, Z.; SÜLI, J.; ŠVRČK, Š.; MOJŽIŠ OVA, J.; TAKÁČOVA, D.; ZÁVADOVÁ, J.; ONDREJKA, R.; ONDREJKOVÁ, A. Experimental inactivated purified concentrated adjuvant rabies vaccine. Evaluation of its efficacy in cattle. Acta Veterinaria BRNO, Palackého, v. 69, n. 1, p. 39-44, 2000. 
CIUCHINI, I. A.; PESTALOZZA, S.; TRANI, L.; ANTONUCCI, G. Risposta immunitaria in bovini vaccinati contro la rabia com virus atenuado ceppo ERA. Revista di Zootecnia e Veterinária, Milano, v. 9, p. 176184, 1981.

FRANKA, R.; SVRCEK, S.; MADAR, M.; KOLESAROVA, M.; ONDREJKOVA, A.; ONDREJKA, R.; BENISEK, Z.; SULI, J.; VILCEK, S. Quantification of the effectiveness of laboratory diagnostics of rabies using classical and molecular-genetic methods. Veterinárí Medicina, Czech, v. 49, n. 7, p. 259-267, 2004.

GIOMETTI, J.; CHIACCHIO, S.B.; ALBAS, A.; PARDO, P.E.; BREMER NETO, H.; GIOMETTI, A. I.; REIS, L. S. L. S. Influência da suplementação com crômio na resposta imune humoral anti-rábica em bovinos. Arquivos do Instituto Biológico, São Paulo, v. 73, n. 4, p. 421-427, 2006

GOMES, M. N.; MONTEIRO, A. M. V.; NOGUEIRAFILHO, V. S.; GONÇALVES, C. A. Áreas propícias para o ataque de morcegos hematófagos Desmodus rotundus em bovinos na região de São João da Boa Vista, Estado de São Paulo. Pesquisa Veterinária Brasileira, Seropédica, v. 27, n. 7 , p. $307-313,2007$

GOMES, M. N.; UIEDA, W.; LATORRE, M. R. D. O. Influência do sexo de indivíduos da mesma colônia no controle químico das populações do morcego hematófago Desmodus rotundus (Phyllostomidae) no estado de São Paulo. Pesquisa Veterinária Brasileira, Seropédica, v. 26, n. 1, p. 38-43, 2006

LIMA, E. F.; RIET-CORREA, F.; CASTRO, R. S.; GOMES, A.A. B.; LIMA, F. S. Sinais clínicos, distribuição das lesões no sistema nervoso e epidemiologia da raiva em herbívoros na região nordeste do Brasil. Pesquisa Veterinária Brasileira, Seropédica, v. 25, n. 4, p. 250254, 2005

MARIA, E. K.; PARDO, P. E.; FRAZATTI-GALLINA, N. M.; PAOLI, R. L.; MOURÃO-FUCHES, R. M.; REIS, L. S. L. S. Efeito da suplementação com zinco na resposta immune humoral anti-rábica em bovinos. In: REUNIÃO ANUAL DA SOCIEDADE BRASILEIRA DE ZOOTECNIA, 44., 2007, Jaboticabal. Anais... Jaboticabal: Sociedade Brasileira de Zootecnia, 2007. p. $1-3$.
PIZA, A. T.; PIERI, K. M. S.; LUSA, G. M.; CAPORALE, G. M. M.; TERRERAN, M. T.; MACAHDO, L. A.; ZANETTI, C. R. Effect of the contents and form of rabies glycoprotein of hte potency of rabies vaccination in cattle. Memórias do Instituto Oswaldo Cruz, Rio de Janeiro, v. 97, n. 2, p. 265-268, 2002.

RODRIGUES DA SILVA, A. C.; CAPORALE, G. M. M.; GONÇALVES, C. A.; TARGUETA, M. C.; COMIN, F.; ZANETTI, C. R.; KOTAIT, I. Antibody response in cattle after vaccination with inactivated and attenuated rabies vaccines. Revista da Sociedade Brasileira de Medicina Tropical, Uberaba, v. 42, n. 2, p. 95-98, 2000.

SCHEFFER, K. C.; CARRIERI, M. L.; ALBAS, A.; SANTOS, H. C. P.; KOTAIT, I.; ITO, F. H. Vírus da raiva em quirópteros naturalmente infectados no Estado de São Paulo, Brasil. Revista de Saúde Pública, São Paulo, v. 41, n. 3, p. 389-395, 2007.

SIHVONEN, L; KULONEN, K.; NEUVONEN, E. Immunization of cattle against rabies using inactivated cell culture vaccines. Acta Veterinaria Scandinavica, Copenhagen, v. 35, n. 4. p. 371-376, 1994.

SMITH, J. S.; YAGER, P. A.; BAER, G. M. A rapid fluorescent focus inhibition test (RFFIT) for determing rabies virus-neutralizing antibody. In: MESTIN, F. X.; KAPLAN, M. M.; KOPROWSKI, H. (Ed.). Laboratory techniques in rabies. Geneva: World Health Organization, 1996. p. 181-192.

WILBUR, L. A.; AUBERT, M. F. A. The NIH test for potency. In: MESLIN, F. X.; KAPLAN, M. M.; KOPROWSKI, H. (Ed.). Laboratory techniques in rabies. Geneva: World Health Organization, 1996. p. 360-368.

ZALAN, E.; WILSON, C.; PUKITIS, D. A microtest for the quantitation of rabies virus neutralizing antibodies. Journal of Biological Standardization, Saskatchewan, v. 7, n. 3, p. 213-220, 1979. 